\title{
Keefektifan Pelayanan Kartu Tanda Penduduk Elektronik (KTP-EL)
}

\author{
Nurfitri Wahyuni, Haedar Akib \& Muhammad Darwis \\ Universitas Negeri Makassar
}

\begin{abstract}
ABSTRAK
Penelitian ini bertujuan untuk mengetahui Keefektian Pelayanan KTP-el pada Kantor Dinas Kependudukan dan Catatan Sipil Kabupaten Bantaeng. Penelitian ini merupakan penelitian deskriptif kualitatif dengan jumlah informan sebanyak 7 orang. Pengumpulan data dilakukan dengan menggunakan teknik observasi, wawancara dan dokumentasi. Sedangkan analisis data yang digunakan terdiri dari empat alur kegiatan yaitu: pengumpulan data, reduksi data, penyajian data dan penarikan kesimpulan (verifikasi).Hasil penelitian menunjukkan bahwa keefektifan pelayanan KTP-el pada Kantor Dinas Kependudukan dan Catatan Sipil Kabupaten Bantaeng berada dalam kategori cukup baik. Melihat fokus dalam penelitian yaitu:1) prosedur pelayanan telah ditetapkan dengan cukup baik, 2) kedisiplinan pegawai berada dalam kategori cukup baik, 3) keadilan pegawai berada dalam kategori cukup baik, 4) keawajaran biaya telah ditetapkan dengan cukup baik, 5) penyamanan pelayanan berada dalam kategori cukup baik.
\end{abstract}

Kata kunci: Efektif, Pelayanan, KTP-EL

\begin{abstract}
This study aims to determine the effectiveness of ID card service at the Office of Population and Civil Registry of Bantaeng Regency. This research is a qualitative descriptive research with the number of informants as many as 7 people. The data were collected using observation, interview and documentation techniques. While the data analysis used consists of four activities: data collection, data reduction, data presentation and conclusion (verification).The results showed that the effectiveness of KTP-el service in the Office of Population and Civil Registry of Bantaeng Regency is in good enough category. Seeing the focus in the research are: 1) the procedure of service has been well established, 2) the discipline of employees are in good enough category, 3) the justice of the employees are in good enough category, 4) the equality of the cost has been set well enough, 5) Are in pretty good category.
\end{abstract}

Keywords: effective, service, KTP-EL

\section{PENDAHULUAN}

Efektivitas merupakan salah satu pencapaian yang ingin diraih oleh sebuah organisasi agar dapat memuaskan masyarakat dan efektivitas secara langsung dapat dihubungkan dengan pencapaian tujuan dari suatu organisasi tersebut. Kata efektivitas itu sendiri memiliki unsurunsur yang memang menjadi perhatikan kepada masyarakat. Masyarakat menuntut pelayanan yang efektif dalam berbagai hal, yakni dalam penyelesaian pekerjaan secara efektif berarti menyelesaikan pekerjaan secara tepat waktu sesuai dengan kuantitasnya serta penggunaan 
sumber daya ataupun output yang minimal dalam mencapai hasil kerja yang maksimal (Hariandja, 2002; Ida Nuraida, 2008; Reza \& Dirgantara, 2010; Tangkilisan, 2005; Umar, 2000).

Salah satu pelayanan terhadap masyarakat adalah pengelolaan pendaftaran penduduk yang merupakan tanggung jawab pemerintah kota/kabupaten, dimana dalam pelakasanaannya diawali dari desa/kelurahan selaku ujung tombak pendaftaran penduduk, hingga setiap warga terdaftar secara administrasi sebagai warga negara Indonesia dan sesuai dengan UndangUndang Nomor 24 Tahun 2013 tentang Kartu Tanda Penduduk elektronik (KTP-el). Satu perubahan besar yang dimunculkan melalui Kartu Tanda Penduduk elektronik (KTP-el) adalah dokumen kependudukan yang memuat sistem keamanan/pengendalian baik dari sisi admininstrasi ataupun teknologi informasi dengan berbasis pada database kependudukan nasional (Taqwa, 2011). Penduduk hanya diperbolehkan memiliki satu Kartu Tanda Penduduk (KTP) yang tercantum Nomor Induk Kependudukan (NIK) yang merupakan identitas tunggal setiap penduduk dan berlaku seumur hidup. Berdasarkan Undang-Undang Nomor 23 Tahun 2006 Pasal 13 tentang Administrasi Induk bahwa:

NIK yang ada di Kartu Tanda Penduduk elektronik (KTP-el) akan dijadikan dasar dalam penerbitan Paspor, Surat Izin Mengemudi (SIM), Nomor Pokok WAjib Pajak (NPWP), Polis Asuransi, Sertifikat atas Hak Tanah dan penerbitan dokumen identitas lainnya.

Bardasarkan Peraturan Daerah Nomor 26 Tahun 2007 tentang kedudukan, tugas pokok dan fungsi Dinas Kependudukan dan Catatn Sipil pasal 19 Dinas Kependudukan dan Catatan Sipil merupakan unsur pelaksana otonomi daerah. Dinas Kependudukan dan Catatan Sipil dipimpin oleh seorang Kepala Dinas yang berada di bawah dan bertanggung jawab kepada Bupati melalui Sekretaris Daerah dan mempunyai tugas melaksanakan urusan Pemerintahan Daerah di Bidang Kependudukan dan Catatan Sipil. Dalam melaksanakan tugas Dinas Kependudukan dan Catatan Sipil menyelenggarakan fungsi seperti Perumusan kebijakan teknis bidang kependudukan dan catatan sipil, penyelenggaraan urusan Pemerintahan dan pelayanan umum bidang kependudukan dan catatan sipil, pembinaan dan pelaksanaan tugas bidang kependudukan dan catatan sipil, pelaksanaan tugas lain yang diberikan oleh Bupati sesuai dengan tugas dan fungsinya.

Kabupaten Bantaeng sebagai salah satu daerah otonom yang sudah mengembangkan $e$ government sedang gencar-gencarnya melakukan perekaman Kartu Tanda Penduduk elektronik (KTP-el) (Jaya, 2011). Hal ini ditunjukan untuk mengejar target penerbitan Kartu Tanda Penduduk elektronik (KTP-el) yang dinstruksikan oleh Kementerian Dalam Negeri. Namun di dalam proses pelaksanaannya masih terdapat kendala ataupun permasalahan yang terjadi. Berdasarkan observasi awal yang dilakukan oleh peneliti pada tanggal 15 September 2016 terkait dengan keefektifan pelayanan Kartu Tanda Penduduk elektronik (KTP-el) pada Kantor Dinas Kependudukan dan Catatan Sipil fakta yang didapat yaitu, interval waktu pencetakan kartu dengan proses perekaman memakan banyak waktu.

\section{METODE PENELITIAN}

Penelitian ini menggunakan penelitian deskritif kualitatif. Penelitian deskritif merupakan suatu penelitian yang dilakukan dengan tujuan utama untuk memberikan gambaran atau dkripsi 
tentang suatu keadaan secara objektif (Moleong, 1999). Peneliti bekerja dengan mempertimbangkan gejala yang diamati serta memanfaatkan catatan lapangan mengenai keefektifan pelayanan KTP-el pada Kantor Dinas Kependudukan dan Catatan Sipil Kabupaten Bantaeng. Adapun yang menjadi informan dalam penelitian ini adalah Kepala bidang administrasi kependudukan yang secara langsung mengendalikan proses pelayanan administrasi kependudukan pada Kantor Dinas Kependudukan dan Catatan Sipil Kabupaten Bantaeng, Masyarakat yang terlibat langsung dan yang pernah terlibat dalam pengelolaan KTP-el pada Kantor Dinas Kependudukan dan Catatan Sipil sebanyak 5 (lima) orang. Untuk memperoleh data pembanding masyrakat yang sementara dan pernah menerima layanan KTP-el adalah pegawai yang ada pada Kantor Dinas Kependudukan dan Catatan Sipil dapat juga dijadikan sebagai informan. Adapun teknik pengumpulan data yang digunakan untuk mengumpulkan data dan informasi yaitu, observasi, wawancara. Dalam melakukan analisis data peneliti mengacu pada beberapa tahapan yang terdiri atas beberapa tahapan antara lain: Pengumpulan data, yakni melalui tiga cara yaitu teknik observasi, teknik wawancara dan teknik dokumentasi, Reduksi data, yaitu membuat rangkuman, Penyajian data, yaitu penyajian dengan mengambil yang pokok-pokok namun dapat dijamin kesahihannya, kesimpulan data verifikasi, yaitu menarik permasalahan sehingga memungkinkan verifikasi selama penelitian berlangsung yang dikembangkan oleh Miles, Huberman, \& Saldana (2014).

\section{HASIL PENELITIAN PEMBAHASAN}

\section{Analisi Data}

Hasil penelitian di Dinas Kependudukan dan Catatan Sipil Kabupaten Bantaeng yang diperoleh dari hasil wawancara guna mengungkap pelayanan Kartu TandaPenduduk Elektronik (KTP-el) di sajikan berdasarkan defenisi konsep penelitian, yaitu: prosedur pelayanan, kedisiplinan petugas pelayanan, keadilan mendapatkan pelayanan, kewajaran biaya pelayanan dan kenyamanan lingkungan.

\section{Prosedur Pelayanan}

Prosedur pelayanan merupakan rangkaian proses atau tata cara yang berkaitan satu sama lain, sehingga menunjukkan adanya tahapan secara jelas dan pasti serta cara-cara yang harus ditempuh dalam rangka penyelesaian suatu pelayanan. Prosedur pelayanan Kartu Tanda Penduduk Elektronik (KTP-el) sudah seharusnya diatur sedemikian rupa dalam memberikan pelayanan maksimal kepada masyarakat agar pelayanan tersebut dapat berjalan secara efektif dan efisien. Prosedur pelayanan yang dimaksudkan untuk memberikan kejelasan kepada masyrakat tentang tata cara pengurusan Kartu Tanda Penduduk Elektronik (KTP-el), ada beberapa ketentuan dan syarat-syarat yang mesti dilakukan oleh masyarakat sebelum ke Dinas Kependudukan dan Catatan Sipil.

Berdasarkan keterangan Kepala Bidang Administrasi kependudukan Dinas kependudukan dan Catatan Sipil menjelaskan bahwa: 
Mekanisme/prosedur pelayanan Kartu Tanda Penduduk Elektronik (KTP-el) tetap mengacu kepada database berdasarkan kecamatan dan kelurahan setempat, setelah itu diberikan panggilan untuk melaksanakan perekaman Kartu Tanda Penduduk Elektronik (KTP-el), lanjut setelah diberikan panggilan untuk perekaman masyrakat hanya membawa fotocopy Kartu Keluarga ( Bapak Amiruddin, SH,. M.Si wawancara, 18 Februari 2017)

Uraian di atas sejalan dengan pernyataan warga/masyrakat yang sedang mengurus Kartu Tanda Penduduk Elektronik (KTP-el) mengungkapkan bahwa:

Prosedur pelayanan yang diberikan oleh pegawai Dinas Kependudukan dan Catatan Sipil sudah jelas dan terarah sesuai dengan apa yang diharapkan dalam pembuatan Kartu Tanda Penduduk Elektronik (KTP-el). (Ibu Nurfahimah, wawancara 20 Februari 2017)

Hal ini senada dengan keterangan masyarakat yang pernah mengurus Kartu Tanda Penduduk Elektronik (KTP-el) yang bertempat ditinggal di kecamatan Bantaeng mengatakan bahwa:

Berkas yang dibawa ke Dinas Kependudukan dan Catatan Sipil untuk mengganti Kartu Tanda Penduduk Elektronik (KTP-el) akibat salah data yaitu Kartu Tanda Penduduk Elektronik (KTP-el) yang salah data, formulir permohonan dan fotocopi kartu keluarga. (Bapak Bahar, wawancara 21 Februari 2017)

Berdasarkan pemaparan diatas, maka penerapan alur/prosedur pelayanan Kartu Tanda Penduduk Elektronik (KTP-el) pada Dinas Kependudukan dan Catatan Sipil sudah berjalan sesuai dengan prosedur pelayanan yang jelas dan pati sehingga masyarakat yang dilayani merasa mendapat kejelasan dan kepastian tentang penyelenggaraan pelayanan.

\section{Kedisiplinan Petugas Pelayanan}

Kedisiplinan petugas merupakan kesungguhan pegawai dalam memberikan pelayanan kepada masyrakat yang dilihat daripada konsistensi waktu kerja sesuai dengan ketentuan yang berlaku yang meliputi disiplin waktu ditempat kerja, menyelesaikan pekerjaan yang diberikan tepat waktu dan jam pullang kerja pada waktu yang telah ditentukan. Disiplin dapat dilaksanakan melalui dua cara, yaitu melalui pengembangan disiplin pribadi yaitu pengembangan disiplin yang datang dari individu dan melalui penerapan tindakan disiplin yang ketat, artinya seoarang pegawai yang melakukan tindakan secara tidak disiplin dikenai hukuman atau sanksi sesuai dengan tingkat kesalahannya.

Bagi pegawai, kedesiplinan harus menjadi acuan hidupnya. Tuntutan masyarakat akan pelayanan semakin tinggi membutuhkan aparatur pegawai pemerintah yang bersih, berwibawah, dan berdisplin tinggi dalam mejalankan tugasnya. Sikap dan perilaku seorang pegawai dapat dijadikan panutan atau keteladanan bagi Pegawai Negeri Sipil yang berada dilingkungannya dan msyarakat pada umumnya. Dalam melaksanakan tugas sehari-hari mereka harus mampu mengendalikan diri sehingga suasana kerja berjalan secara harmonis. Oleh karena itu, dimensi yang dapat digunakan untuk melihat indikator kedisiplinan dapat diukur dari ketaatan, ketepatan, kepatuhan, kesetian, dan tanggung jawab. Kedisiplinan pegawai mengandung kriterria patuh dan menghormati peraturan atau tata tertib yang diatur oleh organisasi tempat pegawai bertugas. Bagi aparatur pemerintah, disiplin mencakup unur-unsur ketaatan, kesetiaan, 
Nurfitri Wahyuni, dkk, Keefektifan Pelayanan Kartu Tanda Penduduk Elektronik (KTP-EL) $\mid 5$

kesungguhan dalam menjalankan tugas dan kesanggupan berkorban. Hal ini berarti kita harus mengorbankan kepentingan pribadu dan golongan untuk kepentingan negara dan masyarakat.

Berdasarkan keterangan warga/masyarakat yang sementara mengurus Kartu Tanda Penduduk Elektronik (KTP-el) mengatakan bahwa:

Pegawai yang ada pada Kantor Dinas Kependudukan dan Catatan Sipil dalam memberikan pelayanan cukup disiplin, cepat dan tepat waktu dalam memberikan pelayanan. (Bapak Azis wawancara 23 Februari 2017)

Hal ini senada dengan apa yang dikatakan oleh staf pelayan Kartu Tanda Penduduk Elektronik (KTP-el) menjelaskan bahwa:

Mengenai kedipsinan yang kami laksanakan dalam memberikan pelayanan kepada masyarakat sudah disiplin karena dalam hal ini kami mulai memberikan waktu pelayanan dimulai pada jam 08.00-12.00 Wita.(Ibu Selfi Minarti wawancara 20 Februari 2017)

Namun berdasarkan hasil penelitian yang diperoleh oleh peneliti melalui observasi langsung pada Kantor Dinas Kependudukan dan Catatan Sipil 20 Februari ternyata masih belum sepenuhnya bias diakatakan dispin. Hal ini terlihat dengan masih ada staf pelayanan yang mengobrol dengan pegawai lainnya pada saat memberikan pelayanan kepada masyarakat.

Berdasarkan uraian diatas mnunjukkan bahwa pegawai kantor Dinas Kependudukan dan Catatan Sipil di bagian pelayanan dalam memberikan pelayanan Kartu Tanda Penduduk Elektronik (KTP-el) kepada masyarakat belum mencerminkan sikap disiplin.Sehingga hal menjadi salah satu pekerjaan rumah bagi Pegawai Negeri Sipil secara umum dan Pegawai Staf Kantor Dinas Kependudukan dan Catatan Sipil Kab Bantaeng sebagai pelayan masyarakat harus mengedepankan sikap profesional dalam memberikan pelayanan demi terciptanya pelayanan yang prima sesuai cita-cita prinsip Good Governance.

\section{Keadilan Mendapatkan Pelayanan}

Keadilan merupakan suatu keharusan yang mesti dilakukan oleh pegawai dalam memberikan pelayanan kepada masyarkat dengan tidak melihat dari sisi status seperti ekonomi, kekeluargaan dan jabatan masyarakat yang dilayani sehingga dalam memberikan pelayanan Kartu Tanda Penduduk Elektronik (KTP-el) cukup adil dan masyrakat merasa tidak dibedabedakan antara yang satu dengan yang lainnya. Oleh karena keadilan sangatlah diinginkan oleh masyarakat berkenan dengan sikap pegawai dalam memberika pelayanan antara satu dengan yang lainya dan memperlakukannya sesuai dengan hak dan kewajiban serta mendahulukan yang lebih awal datang dan tidak dipandang bulu atau pilih kasih melainkan semua masyarakat yang dilayani dalam hal pengurusan Kartu Tanda Penduduk Elektronik (KTP-el).

Keadilan mempunyai dua aspek yaitu, keadilan moral, merupakan keadilan yang terjadi apabila mampu memberikan perlakuan seimbang antara hak dan kewajibannya dan keadilan prosedural adalah keadilan yang terjadi apabila seseorang melaksankan perbuatan sesuai dengan tata acara yang diharapkan. Pemahaman yang baik mengenai keadilan dalam pemberian pelayanan kepadda masyrakat yang sedemikian rupa sehingga pemahaman tersebut menumbuhkan pengertian yang mendalam atau kesadaran bahwa keadilan merupakan syarat mutlak untuk mencapai keberhasilan dalam pelayanan. Sikap dan perilaku yang wajar 
6| Jurnal Ilmiah Ilmu Administrasi Publik, Vol.7, No.1, 2017

menunjukkan kesungguhan hati untuk menaati segala hal secara cermat dan tertib baik dalam melaksanakan tugas pelayanan maupun tugas administrasi lainnya yang diberikan oleh atasan.

Berdasarkan keterangan Kepala Bagian Administrasi Kepegawaian menjelaskan bahwa: Dalam memberikan pelayanan kepada masyarakat untuk pelayanan Kartu Tanda Penduduk Elektronik (KTP-el) dalam hal ini kami tidak melihat dari latar belakang masyrakat, siapapun dia, kami perlakukan sesuai dengan peraturan yang berlaku, baik itu masyarkat dari kalangan mikin maupun sebaliknya, kami perlakukan sama antara yang satu dengan yang lainnya dan mendahulukan yang mana awal duluan datang maka yang itulah kami layani dulu. (Bapak Amiruddin, SH., M.Si wawancara 18 Februari 2017)

Hal tersebut senada dengan keterangan warga/masyarakat yang sedang mengurus Kartu Tanda Penduduk Elektronil (KTP-el) mengatakan bahwa:

Pegawai yang berada di kantor Dinas Kependudukan dan Catatan Sipil dalam memberikan pelayanan Kartu Tanda Penduduk Elektronik (KTP-el) memberikan pelayanan secara adil serta tidak melihat dari pada status jabatan atau ekonomi yang saya miliki, itu dikarenakan mereka menggunakan sistem antrian. (Ibu Nuraeni, S.Pd wawancara 25 Februari)

Uraian diatas sejalan dengan pernyataan warga/masyarakat yang pernah mengurus Kartu Tanda Penduduk Elektronik (KTP-el) mengungkapkan bahwa:

Pegawai yang berada di Kantor Dinas Kependudukan dan Catatan Sipl dalam memberikan pelayanan yang sama dengan masyarakat yang lainnya karena menggunakan sistem antrian. ( Ibu Haerati wawancara 27 Februari 2017)

Berdasarkan pemaparan diatas, maka pelayanan Kartu Tanda Penduduk Elektronik (KTPel) mengenai keadilan dalam pemberian pelayanan kepada masyarakat cukup efektif sehingga masyarakat yang dilayani tidak dibeda-bedakan antara satu dengan yang lainnya.

\section{Kewajaran Biaya Pelayanan}

Kewajaran biaya merupakan masyarakat yang dilayani sesuai dengan besarnya biaya yang ditetapkan oleh uni pelayanan pada instansi pemerintah tersebut secara wajar dengan memperhatikan nilai barang dan jasa pelayanan serta tidak memungut biaya yang tinggi diluar kewajaran kondisi masyarakat untuk membayarkan secara umum. Sehingga masyarakat yang dilayani merasa tidak terbebani dengan biaya yang telah ditetapkan. Dalam menentukan kewajaran biaya pelayanan kepada masyarkat harus benar-benar sesuai/relevan dengan jenis pelayanan yang akan diberikan.kewajaran biaya pelayanan tersebut harus diinformasikan secara jelas kepada masyarakat sehingga masyarkat yang mendapat pelayanan merasa tidak di rugikan.

Menurut sebagai warga/masyarkat yang sementara mengurus Kartu Tanda Penduduk Elektronik (KTP-el) mengungkapkan bahwa:

Kewajaran biaya yang diberikan oleh pegawai Staf pelayanan dalam memberikan pelayanan Kartu Tanda Penduduk (KTP-el) tidak ada biaya saya keluarkan sedikitpun. (Ibu Nurfahimah, wawancara 20 Februari 2017)

Uraian diatas sejalan dengan keterangan warga/masyarakat yang pernah mengurus Kartu Tanda Penduduk Elektronik (KTP-el) mengungkapkan bahwa: 
Nurfitri Wahyuni, dkk, Keefektifan Pelayanan Kartu Tanda Penduduk Elektronik (KTP-EL)|7

Dari awal hingga saya mendapatkan Kartu Tanda Penduduk Elektronik (KTP-el) pegawai staf pelayanan khususnya pelayanan Kartu Tanda Penduduk Elektronik (KTP-el) tidak penah meminta pungutan biaya kepada masyarakat. (Ibu Haerati wawancara 27 Februari 2017) bahwa:

Hal tersebut senada dengan apa yang dikatakan oleh Staf Pelayanan KTP-el menjelaskan

Berbicara mengenai biaya mulai tahun 2008 hingga sekarang Dinas Kependudukan dan Catatan Sipil Kabupaten Bantaeng gratis, tidak ada biaya yang dikeluarkan oleh masyarakat khususnya dalam pelayanan administrasi kependudukan. .(Ibu Selfi Minarti wawancara 20 Februari 2017)

Adapun menurut Kepada Bidang Administrasi Kependudukan mengatakan bahwa: Kami tidak meminta biaya kepada masyarakat sedikitpun untuk semua pengurusan dokumen kependudukan karena Dinas Kependudukan dan Catatan Sipil menerima alat dan blanko dari pusat sehingga tidak ada biaya yang dikeluarkan oleh masyrakat. (Bapak Amiruddin, SH,. M.Si wawancara, 18 Februari 2017)

Berdasarkan uraian tersebut diatas, dapat diketahui bahwa pegawai Dinas Kependudukan dan Catatan Sipil tidak meminta pungutan biaya dari masyarakat dalam pengurusan dokumen kependudukan.

\section{Kenyaman Pelayanan}

Kenyamanan pelayanan terkait dngan ketersediaan sarana prasarana pelayanan yang berada dalam kondisi yang bersih, rapi serta teratur sehingga memberikan rasa nyaman kepada masyarakat yang dilayani. Sarana prasarana yang dimaksud fasilitas kerja yang digunakan oleh pegawai dalam menjalankan tugasnya dengan baik maupun fasilitas yang disiapkan untuk masyarakat yang menerima layanan sehingga dapat memberikan kepuasan kedua belah pihak.

Lingkungan kerja yang baik biasanya terwujud apabila fasilitas kerja yang memadai sehingga dapat menciptakan suasana kerja yang nyaman dan aman bagi pegawai yang pada akhirnya akan mengurangi kejenuhan dan kebosanan seperti bangunan gedung, peralaan kerja atau ruang kerja yang menarik dan menyenangkan dalam arti cukup luas dan lapang, serta teratur dan tertata rapi. Selain itu dukungan sarana prasarana pendukung pelaksanaan tugas pelayanan juga diperlukan seperti tempat ibadah, kantin dan kamar kecil. Hal ini tidak kalah pentingnya pula adalah mengutamakan keselamatan kerja.

Menurut Kepala Bidang Administrasi kependudukan mengatakan bahwa:

Kondisi dan ruangan yang kami gunakan dalam memberikan pelayanan kepada masyarakat kurang nyaman karena tidak sesuai dengan unsur pelayanan, Dinas Kependudukan dan Catatan Sipil ini tidak mempunyai gedung kantor sendiri, merupakan kantor yang masih menumpang dengan kantor BKKBN.

Hal tersebut senada dengan keterangan staf Pelayanan Kartu Tanda Penduduk Elektronik (KTP-el) mengatakan bahwa:

Sarana yang digunakan kurang memadai karena komputer yang digunakan hanya beberapa yang berfungsi sehingga mengakibatkan pelayanan terhadap masyarakat terhambat, kondisi ruangan 
8| Jurnal Ilmiah Ilmu Administrasi Publik, Vol.7, No.1, 2017

yang sangat minim dan memprihatinkan karena ruangan yang sempit, pengap dan panas sehingga tidak memenuhi persyaratan pelayanan prima. .(Ibu Selfi Minarti wawancara 20 Februari 2017)

Hal ini sesuai dengan keterangan warga/masyarakat mengatakan bahwa:

Kenyamanan pemberian pelayanan yang ada pada Kantor Dinas Kependudukan dan Catatan Sipil sangat minim, hal ini dikarenakan kondisi ruangan yang sempit sehingga masih banyak diantara kami yang mengantri dalam keadaan berdiri atau menunggu diluar kantor. (Bapak Azis wawancara 23 Februari 2017)

Selanjutnya, hal tersebut sejalan dengan observasi langsung yang dilakukan oleh peneliti pada Kantor Dinas Kependudukan dan Catatan Sipil (20 Februari 2017) di peroleh bahwa kenyamanan pelayanan pada Kantor Dinas Kependudukan dan Catatan Sipil sangat minim dalam memberikan pelayanan. Hal ini ditunjukkan dengan adanya foto dokumentasi yang tertera pada lampiran pada Kantor Dinas Kependudukan dan Catatan Sipil. Berdasarkan uraian tersebut diatas, jelaslah bahwa kenyamanan pelayanan yang ada pada Kantor Dinas Kependudukan dan Catatan Sipil dikatakan sangat minim.

\section{Pembahasan}

Pentingnya pengurusan administrasi kependudukan pada Kantor Dinas Kependudukan dan Catatan Sipil Kabupaten Bantaeng karena dengan adanya data kependudukan seperti Kartu Keluarga (KK), Kartu Tanda Penduduk Elektronik (KTP-el), Akta Kelahiran dan sebagainya. Hal ini dimiliki seseorang itu memberikan sebagai bukti atas suatu kepemilikan dan hal ini yang menjadi identitas yang sah bagi yang dimilikinya. Proses pengurusan administrasi kependudukan juga mempunyai prosedur tersendiri yang harus dilaksanakan oleh para pegawai yang memeliki kewenangan dalam memberikan pelayanan kepada masyarakat atas kebutuhannya tentang administrasi kependudukan.

Pemberian pelayanan yang diberikan kepada masyrakat yang mempunyai kepentingan pada Kantor Dinas Kependudukan dan Catatan Sipil Kabupaten Bantaeng. Sebagaimana telah dikemukakan terlebih dahulu bahwa pemerintahan pada hakekatnya adalah pelayanan kepada masyarakat, bukan melayani dirinya sendiri, tetapi untuk melayani masyarakat serta menciptakan kondisi yang memungkinkan setiap anggota masyarkat mengembangkan kemampuan dan kreativitasnya demi mencapai tujuan bersama. Karena birokrasi publik berkewajiban dan bertanggung jawab untuk memberikan layanan baik dan profesional. Kemampuan aparat secara nyata untuk melayani, membantu, dan mengurus apa-apa yang dibutuhkan oleh masyarkat yang secara aktif akan memudahkan dan melancarkan proses pekerjaan yang mereka lakukan dengan benar dan tepat waktu.

Dalam proses pelayanan Kartu Tanda Penduduk Elektronik (KTP-el) oleh pemerintah daerah ada beberapa hal yang belum mampu dilaksanakan. Hal tersebut dapat peneliti melihat terhadap kurangnya kedisiplinan pegawai ketika memberikan pelayanan kepada masyarakat. Terdapat beberapa faktor yang dapat menghambat pelaksanaan proses pelayanan Kartu Tanda Penduduk Elektronik (KTP-el) pada Kantor Dinas Kependudukan dan Catatan Sipil Kabupaten Bantaeng, antara lain: kedisiplinan kerja dari pegawai yang masih kurang padahal efektivitas kerja pegawai akan nilai dari hasil kerja yang mereka lakukan dan kenyamanan pelayanan yang 
Nurfitri Wahyuni, dkk, Keefektifan Pelayanan Kartu Tanda Penduduk Elektronik (KTP-EL)|9

sangat minim karena pelayanan yang berikan kepada masyarakat merupakan tanggung jawab yang harus dipenuhi dalam keadaan apapun. Selain dari pada itu mengenai beberapa prosedur pelayanan, keadilan pelayanan, kewajaran biaya sudah cukup baik sehingga perlu dipertahankan atau lebih ditingkatkan lagi karena merupakan salah satu faktor pendukung untuk terlaksananyan suatu pelayanan Kartu Tanda Penduduk Elektronik (KTP-el) pada Kantor Dinas Kependudukan dan Catatan Sipil Kabupaten Banateng dapat berjalan dengan baik.

\section{SIMPULAN}

Pelayanan Kartu Tanda Penduduk Elektronik pada Kantor Dinas Kependudukan dan Catatan Sipil Kabupaten Bantaeng secara keseluruhan sudah cukup optimal. Hal ini karena adanya standar pelayanan yang ditetapkan sebagai pedoman dalam memberikan pelayanan Kartu Tanda Penduduk (KTP-el) kepada masyarakat. Hal tersebut dapat dilihat dari pada mekanime/prosedur pelayanan Kartu Tanda Penduduk Elektronik (KTP-el), pelayanan yang dilakukan mengikuti prosedur yang ada sehingga masyarakat merasa jelas dan terarah. Adapun petugas pelayanan masih kurang dalam memperlihatkan kedisiplinan dalam memberikan pelayanan kepada masyarakat hal ini disebabkan masih adanya staf pelayanan yang tidak berada dalam ruangan pada saat memberikan pelayanan kepada masyarakat. Selanjutnya keadilan pelayanan yang di berikan pegawai kepada masyarakat termasuk cukup adil dalam hal pelayanan Kartu Tanda Penduduk (KTP-el) itu dikarenakan dari beberapa hasil wawancara masyarakat begitupun mengenai kewajaran biaya pelayanan pegawai yang dilaksanakan dalam memberikan pelayanan Kartu Tanda Penduduk Elektronik (KTP-el) cukup wajar, hal ini dikarenakan dalam pemberian pelayanan administrasi kependudukan khususnya Kartu Tanda Penduduk Elektronik (KTP-el) tidak di kenakan biaya atau gratis dan yang terakhir kondisi ruangan dan sarana pelayanan yang sangat minim, sehingga masih perlu ditingkatkan dalam rangka memberikan kenyamanan dan pelayanan Kartu Tanda Penduduk Elektronik (KTP-el) menjadi lebih optimal.

\section{DAFTAR PUSTAKA}

Hariandja, M. T. E. (2002). Manajemen sumber daya manusia. Grasindo.

Ida Nuraida, S. E. (2008). Manajemen Administrasi Perkantoran. Kanisius.

Jaya, F. (2011). Analisis Kesiapan Pemerintah Kota Palopo dalam Penyelenggaraan EGovernment. Universitas Hasanuddin.

Miles, M. B., Huberman, A. M., \& Saldana, J. (2014). Qualitative Data Analysis: A Methods Sourcebook (3rd ed.). United States of America: Sage Publications.

Moleong, L. J. (1999). Metodologi penelitian. Bandung: PT. Remaja Rosda Karya.

Reza, R. A., \& Dirgantara, I. (2010). Pengaruh gaya kepemimpinan, motivasi dan disiplin kerja terhadap kinerja karyawan PT Sinar Santosa Perkasa Banjarnegara. Universitas Diponegoro.

Tangkilisan, H. N. S. (2005). Manajemen publik. Grasindo.

Taqwa, S. (2011). Aplikasi pembuatan E-KTP (Kartu Tanda Penduduk) menggunakan barcode berbasis Web; studi kasus: Kabupaten Tanjung Jabung Timur Provinsi Jambi. UIN Syarif 
10| Jurnal Ilmiah Ilmu Administrasi Publik, Vol.7, No.1, 2017

Hidayatullah Jakarta.

Umar, H. (2000). Business an introduction. Gramedia Pustaka Utama. 